\title{
Phenomenology, Existentialism and Postanalytic Philosophy in Modern Social Cognition: Attitude Positions*
}

\author{
Anna Ivanova \\ Bauman Moscow State Technical University \\ 5/1, 2nd Baumankaya Str. \\ Moscow, Russia 105005 \\ E-mail: anna-msu@yandex.ru
}

\begin{abstract}
The article considers the phenomenological theory interrelation with some other directions of modern socio-philosophical discourse, primarily - with existentialism. We formulated the difference between the phenomenology of M. Heidegger and existentialism J.-P. Sartre. Considered existential sociology of E. Tiryakian. Specificity of the social phenomenology of A. Schütz was determined.As a result, we come to a conclusion about the illegalityof uncritical convergenceof social phenomenology and existentialism but there also exists a conceptual connection between phenomenological sociology and postanalytic philosophy.
\end{abstract}

Keywords-social phenomenology; existentialism; social constructivism; ethnomethodology; postanalytic philosophy

\section{INTRODUCTION}

In fact, making close the existential sociology with the consideration of society in the phenomenological perspective became a common place in the pages of specialized literature. Existential direction in social theory was formed in the 60-es and 70-es; its key representatives were Edward Tiryakian and Jack Douglas, and in addition, we should mention the Joseph A.Kotarba's and John Johnson'snames [1] [2] [3].The ideaof J.-P. Sartre's heritage sociological reading belongs to the researcher Gile Heim [4]. These authors are often consideredin the framework of the "existentialphenomenological direction". In particular, the domestic researcher A.S. Melnikov, analyzing the "problem field of existential sociology", interprets the latter as a phenomenological tradition element, along with A. Schütz, G. Garfinkel [5].The reduction of both directions to the "common denominator" is performed on the "humanistic accents" principle which, in the author's opinion, considering the social worldboth phenomenologists and existentialists takes into account. We believe that the "humanistic perspective," in terms of which some researchers speak about phenomenological sociology [6], is justified only to a certain limit. We should not forget that the basis of existential and

*This work was carried out with the financial support of the Russian Foundation for Basic Research in the framework of the scientific project No. 18-311-00157 "Mol a" "Development of post-non-classical methodology of social cognition". phenomenological sociology is the basic philosophical principles, which seem to differ significantly. We will explain.

\section{SOCIAL PHENOMENOLOGY AND EXISTENTIALISM: COMPARATIVE ANALYSIS}

Existentialism is a truly anthropological version of philosophizing. The problem of Sense for existentialists becomes the problem of the meaning of life. For phenomenologists, this is by no means the case. Both E. Husserl and M. Heidegger rejected philosophizing «on anthropological basis». In this, they are one: anthropocentrism accusations, addressed by Husserl to Max Scheler, are extremely similar to the Sartre's philosophy assessments by Heidegger.Let us refer to the statements of the philosophers themselves. In his correspondence with $G$ Mishu, Husserl speaks of Sheler'sheritageas the cause of "becoming dominant misunderstanding"of his ownphilosophy [7]. Phenomenology, as Husserl states, "should not be understood according to Scheler" [Ibid.]. He means his anthropological project. As for Heidegger's position on the stated problem, it is enough to recall the "Letter on Humanism": the "humanistic" perspective in the opinion of $\mathrm{M}$. Heidegger is inevitably metaphysical. The turning around of the "essence" and "existence" does not overcome metaphysics - the existential perspective will always be "the interpretation of the essence bypassing the question of the truth of being." The "Letter on Humanism" is known to be a direct Heidegger's response to the J.-P. Sartre's program text: "Existentialism is a Humanism." Moreover, it is in the light of Sartre's philosophy, in our opinion, that existential sociology must be understood.

In this regard, we will refer tothe standpoint of $\mathrm{E}$ Tiryakian, this direction founder: "Since the main existential thinkers emphasize the fundamental difference between authentic and non-authentic existence, it is necessary to investigate sociologically the conditions under which society ... exists authentically or non-authentically" [8].

Thus, Tiryakianadopts the terminological distinction between "authentic and non-authentic" existence. For him, 
the Subject can "be", but can "seem". In the phenomenological sociology, from our point of view, the constructivist perspective will prevail. A. Schütz, G. Garfinkel and al. will not be occupied by the discovery of an "authentic" dimension of the human personality and, as a consequence, by attempts to return the person to himself. They willbe interested not in the opposition "authentic -nonauthentic", but, rather, in ways of these predicates social fixation in the life strategies. The "projectivity" of human existence - the Sartre's philosophy visiting card - should not mislead us in this case: Sartre's "constructivism" is not at all phenomenological. The existential philosophy proceeds from the absolute separation of the Subject's perspective and the one of external world. The setting for sovereignty turns into an interpretation of "designing oneself" as "winning back oneself from the world, the socium" [9]. But within the framework of the phenomenological tradition, the "situation", "circumstances" do not take away our freedom; on the contrary, they make it possible: I am free, not in spite of circumstances, but thanks to them.M. Merlo-Ponty once clearly formulated this position. However, Sartre's types of "the design of consciousness" - "have", "do", "be" - do not complement each other but, rather, exclude each other [10].To the pathos of human reality, which is not reducible to anything, phenomenologists oppose the perspective of "Werelations". This is the position of Alfred Schütz: "... "...The experience of "We"(in the closest surroundings) is the basis of the "I" experience with respect to the world in general" [11]. This approach is strikingly different from the interpretation of "We" by J.-P. Sartre. The term "WeSubject"he defines as a "psychological", but not an "ontological experience". The notion "We"Sartre understands only as a mechanical combination of my perspective and the perspective of the other, given in the situation of the initial conflict. While according to social phenomenologists, "We"is presupposed to our isolated being: "We"is not composed of our "I"; on the contrary, we derive the self from a common perspective [12].

Thus, the existentialists - in an attempt to deal with the "nature of man" - will appeal to the "project" as to an empty self. However, within the framework of phenomenological sociology, the social relations will take the place of the Subject. In this way, the phenomenologists oppose to the mode of isolation of existentialism the one of involvement the interdependence of self and society [13].

We should also point out one more aspect that does not allow us to identify phenomenological sociology as an existential theory. The former can be understood as everyday life sociology, aimed at studying daily reproducible actions, routine practices. The pathos of existential philosophy is clearly opposed to everyday life philosophy - it is oriented, rather, to "outstanding", "extraordinary", etc.The words of E. Tiryakianare characteristic in this regard: "... The opposition of the authentic and the non-authentic is easy to observe in crises - both at an individual and at a collective level. Sociology here should pay attention to the catastrophic situations in which the collective falls, because the catastrophe ... shakes the daily world of society ..." [14].In this way, existential sociology confirms the neo-Kantian principle: "the more exceptional the phenomenon is, the greater is its significance" (G. Rickert). Phenomenological sociology, on the contrary, is "trivial": being convinced that "the nearest lying -is ontologically the most distant", its representatives will appeal to "self-evident", demonstrating that exactly it is truly mysterious and dramatic.

The "material" and "subjective" opposition that Sartre pursued consistently and peremptorily, is also impossible within the framework of phenomenological sociology: everyday life is not given to us divided into "facts" and "meanings," it is syncretic. Another difference at the social level, we should note, is the human action understanding. Existentialism, defining the subject reality in terms of selfrealization, self-actualization, and baseless freedom, brings to the absurd the M. Weber's "actionism". The phenomenological perspective of social action interpreting is not "projective," but rather "retrospective." Phenomenologists focus noton an action as autonomous individual will manifestation, but on practices - routinely reproducible actions inscribed in the context of the situation. The individual in social theory of Alfred Schützdoes not plan and does not think about his action every time, focusing more on what "worked before", and finds his actions explanation post-factum. Within the framework of the "existential" reading, such a person would be accused as a weak person who is giving himself to circumstances: in this case, within the framework of existentialism, it is hard to imagine another alternative to "being of a person", other than "functioning as a social role" [15].

The object of our brief analysis was to demonstrate that in the light of "existentialism as humanism" phenomenological sociology in many respects appears, rather, as "theoretical anti-humanism".

In this connection, we emphasize once again: it is impossible, from our point of view, while characterizing the phenomenological direction in sociology, to confine ourselves to the categories of the "humanistic perspective", the "paradigm of the subject", and so on. Phenomenological sociology, undoubtedly, refers to the subject of the social world, but this does not clarify anything; as the "prospects of the subject" in modern social cognition can be too different.

\section{From THE "StRICT SCIENCE" ProJeCt TO "THE LIFE WORLD": PHENOMENOLOGY AND ANALYTICAL PHILOSOPHY CONVERGENCE TENDENCIES}

Noting some relevance of the phenomenological and existential perspectives non-critical convergence in sociology, we, on the other hand, incline to the idea of phenomenological sociology and postanalytic philosophy interrelation.

Phenomenology and analytical philosophy are the most important "centers of attraction" of philosophical and scientific thought of the Twentieth Century. As part of our consideration, it is not possible to explain sufficiently all their relationships twists and turns. However, in the whole, we can indicate some contact points both at the level of problems and at the level of evolution. Initially, E. Husserl, 
G. Frege, and B. Russell will be oriented to solving theoretical and cognitive problems; they will be united in criticizing psychologism: the meaning is not a subjective experience, but an ideal objectivity. Another thing is that "Sinn" (in German - both "sense" and "meaning")refers to all acts - not only to linguistic meanings according to Husserl.At the same time, we emphasize that their original setting is similar: i.e. an attempt to find a solid basis of any knowledge - either by means of the language logical analysis, or by referring to subjectivity fundamental structures.

Undoubtedly, the problem setting of the both trends evolutionary development parallels is also justified: it is sufficient to trace the transformations in the views about the "knowledge basis" of the two largest phenomenological and analytical representatives, E. Husserl and L. Wittgenstein. From "strict science" and logical atomism, they will pass to the "vital world" and "language games". The movement towards each other, it seems to us, will become possible in perspective reorienting from the "theoretical" reason position to the position of "practical".

Thus, a language initially considered by analytical philosophy at the formal semantics level will be rethought in the word usage pragmatic perspective. From the logical atomism theory, analysts will pass to the everyday language analysis. The latter is only possible as a practice - the one of everyday communication. Thus, analytical philosophy from the problems of the cognition theory will pass to the sociocultural world subject consideration as a practical agent. Here it is appropriate to refer to the works of D. Austin [16], devoted to the problems of performative statements, which are not reality descriptions, but reality creation "actions".

Phenomenological philosophy will also develop in the everyday life socio-cultural world analysis direction. As for the direct connection with the analytical tradition, within the framework of social phenomenology, a "linguistic turn" is also evident: in the early 1940s, Alfred Schütz considered the problem of language as a problem of "styles of everyday thinking, and not the theory of cognition" [17]. Later, first of all,ethno-methodologists - Aron Cicourel [18], Harvey Sachs [19], Rod Watson [20], will analyze the «linguistic» nature of the social. Inheriting the ethnomethodology subject understanding as an everyday reality cognitive system intersubjectively shared, they will turn to "institutionalized structures of conversation" - they will be interested in the conversational practices organizing general principles.

Modern ethnomethodologists, according to N.M. Smirnova, "are united by the conviction that to understand the everyday rationality formal structures, natural language index properties knowledge is necessary" [21]. The latter, in turn, represent the problem of the non-eliminability of the social context in the use of language.

Thus, Aron Cicourel, one of the most famous G. Garfinkel'sfollowers, will develop a theory of the so-called "generating semantics" - he will analyze the values attribution rules to linguistic expressions in the course of direct language communication. Cicourel proceeds from language practice understanding as having socially organized background expectations.
It is they that constitute the communication condition: we come to the partner understanding not by the endless questioning about what is "implied", but relying on the "social stock of knowledge" - we correlate linguistic expression with a broader horizon of sociocultural meanings. In this regard, the scientist also pays special attention to "paralinguistic expressions" - gestures, mimicry.

Cicourel insists on the need to problematize the obvious fact, which has long been ignored by linguists. "What is said" can mean much more than the formal words. Moreover, it is the communication subjects' mastering the techniques and the ability to read correctly their use by the partner(thanks to which "really said" differs from "formally said")that is in many ways the true communication "adequacy" indicator.

We observe it only in the case when many aspects of the described situation are omitted, taken out of brackets. Understanding of these background unexplained meanings is the true understanding. In addition, an attempt to order these hidden meanings by means of formalized linguistic methods leads to the communication destruction. [22].

This does not mean that the scientist is doomed to various colloquial practices unsystematic "accumulation"; he should be interested in the invariant communication characteristics, but not of a formal nature (orientation on the terms uniqueness, their application adequacy), but pragmatic: how individuals come and demonstrate this conversation "correctness". Thus, the central one is the problem by which mechanisms the participants of communication themselves interpret the available language practice as an appropriate norm [23].

Thus, the problem of language today has become firmly established in phenomenology. And while analysts have come a long way from "meaning as a denoter" to "meaning as usage", social phenomenologists have been initially focused on analyzing everyday speech practices.

In this regard, the conclusion about the "natural language" as a point of convergence of the modern postanalytic tradition and phenomenological sociology is justified.

\section{CONCLUSION}

In our review, we criticized the traditional approaching of phenomenological and existential traditions in sociology, indicating their ideological and methodological specifics. In addition, in the process of our analysis, the commonality of the modern problems of consciousness philosophy and the language philosophy wasthematized. While existentialism in an attempt to find the "true" subject dimension will think in terms of "unique personality" and "massification", phenomenologists and analysts will agree on the basis of "accepted as a given" sociocultural everyday life general world,and will appeal to natural language and routinely reproducible practices. 


\section{REFERENCES}

[1] Tiryakian E. Sociologism and Existentialism: Two Perspectives on the Individual and Society.Englewood Cliffs, New Jersey, 1962, p. 176.

[2] Douglas J., Johnson J., eds.Existential Sociology. Cambridge, Cambridge University Press Publ., 1977, p. 327.

[3] Kotarba J., Johnson J., eds.Postmodern Existential Sociology. Walnut Creek, CA Publ., 2002, p. 272.

[4] Hayim G. The Existential Sociology of Jean-Paul Sartre. Amherst, University of Massachusetts Press Publ., 1980, p. 157.

[5] Melnikov A.S. The problematic field of existential sociology.Sociology: theory, methods, marketing, 2008, no. 2, pp.83102.

[6] Abels H. Romance, phenomenological sociology and qualitative sociological research. The Journal of Sociology and Social Anthropology, 1998, vol. 1,no. 1, pp.98-124.

[7] Meckel K.Diagnosis of the crisis: Husserl against Spengler.Logos, Moscow, 2007, no. 6 (63), pp.147-176.

[8] Schütz A.The Problem of Rationality in the Social World.Economica, 1943, vol. 10, no. 38.P. 164.

[9] Lazarev F.V., Lebedev S.A. The Philosophical Reflex: Essence, Form, Types // Voprosyfilosofii. 2016. № 6. P. 15-28.

[10] Sartre J.-P. Being and Nothingness: An Essay on Phenomenological Ontology. London, Methuen Publ., 1958 [In Russ.: Sartre J.-P. Being and Nothingness: The experience of a phenomenological ontology.Moscow,Respublika Publ., 2004, 639 p.

[11] Schutz A. Collected Papers. Vol.I-III.The Hague, 1962-66 [In Russ.:Schütz A. Selected works:The world, glowing with sense.Moscow,ROSSPEN Publ., 2004. P. 888.

[12] Heidegger M. Being and Time. New York, Harper \& Row Publ., 1962 [In Russ.: Being and time.St-Petersburg,NaukaPubl., 2006. P. 438

[13] Gubanov N.I., Gubanov N.N. The role of mentality in the development of society: sociocultural hypothesis // Vestnikslavianskikh kultur-bulletin of slavic cultures-scientific and informational journal. 2017. Vol. 43. № 1. P. 38-51.

[14] Tiryakian E. Sociologism and Existentialism: Two Perspectives on the Individual and Society.Englewood Cliffs, New Jersey, 1962. P. 164.

[15] Komissarov I; Nekhamkin V. The Models of Historical Cognition: Current Status and Prospects of Development // IstoriyaElektronnyinauchno-obrazovatelnyuzhurnal. 2017. Vol. 8. Issue 2. DOI:10.18254/S0001779-5-1

[16] Austin J.L.The meaning of the word.In: Austin J.L., Urmson J.O., Warnock G.J. Philosophical Papers. New York, Oxford University Press Inc. Publ., 1979. [In Russ.: Austin J. The meaning of the word.Analytical Philosophy: Selected Texts. Moscow, MGU Publ., 1993,pp. 105-120.

[17] Schütz A. The Problem of Rationality in the Social World. Economica, 1943,vol. 10, no. 38. P. 83.

[18] Cicourel A. Cognitive Sociology: Language and Meaning in Social Interaction. Harmondsworth, Penguin education Publ., 1973, $191 \mathrm{p}$.

[19] Silverman D., Sacks H. Social Science and conversation analysis. Oxford, Oxford University Press Publ., 1998, 232 p.

[20] Heritage J.C., Watson D.R. FormulationsasConversationalObjects.Everyday Language:Studies in Ethnomethodology, PsathasG.,ed. New York, Irvington Publ., 1979, $310 \mathrm{p}$.

[21] Smirnova N.M.Social phenomenology in the study of modern society.Moscow, Canon + Publ., 2009. P. 297

[22] IvlevV.Yu., Oseledchik M.B. Methodological principles for the introduction of modality categories in modern scientific cognition // Proceedings of the 3-rd International Conference on Arts, Design, and Contemporary Education. (ICADCE 2017) Advances in Social Science, Education and Humanities Research». Paris: Atlantis Press, 2017. V.144. Pp.541-545.
[23] IvlevV.Yu., Lepskaya N.D.Modalities and logic // "Proceedings of the 2017 2nd International Conference on Contemporary Education, Social Sciences and Humanities". (ICCESSH 2017), Part of the series ASSEHR. Moscow, Russia. V.124. P.79-86. 